\title{
四面体辺要素を用いた三次元有限要素法による 直流電磁石の過渡動作特性の数値解析
}

\author{
正員 河 瀬 順 洋 (岥 阜 大) \\ 正員 菊 地 春 秀 (電算システム)
}

\section{3-D Dynamic Analysis of DC Electromagnet using Finite Element Method with Tetrahedral Edge Elements}

Yoshihiro Kawase, Member (Gifu University), Haruhide Kikuchi, Member (Densan System Co., Ltd.)

To design DC electromagnets in an optimal manner, it is necessary to obtain the dynamic behavior accurately. A new method to calculate the dynamic behavior using the finite element method with edge elements has been developed. In order to verify its accuracy, the static and the dynamic behaviors of a clapper type electromagnet are calculated. The 3-D electromagnetic field analysis is carried out using the vector finite element with tetrahedral edge variables. The force is obtained by using the Maxwell stress tensor. The displacement of the armature of the electromagnet is obtained by solving the motion equation of the moving parts. The calculated results of the edge elements and that of the nodal elements are compared with the measurements. Moreover, it is clarified that the forces and the dynamic behavior can be accurately calculated using the edge elements.

キーワード : 三次元, 有限要素法, 辺要素, 電磁石, 非線形, 運動方程式, 電磁力

\section{1.まえがき}

磁気を応用した電気・電子機器の最適設計のために 種々の努力がはらわれているが, 従来は試作品による 実験的検討がほとんどであった。今日コンピュータお よび各種数值解析法の発達により, 計算機支援設計が 広く用いられている。既に著者らは, 三次元場におい て四面体節点要素を用いた有限要素法による電磁石の 過渡動作解析法を開発し，ヒンジ形直流電磁石に応用 し，その有用性を明らかにするとともに動作特性に及 郡諸因子について検討しだ(1)(2)。

近年, 従来の末知数が節点で定義される要素ではな く, 辺で定義される新しい要素である辺要素が提案さ れており(3) (6), 解析精度や計算時間などについても 検討されている(7) (9)。しかし, 従来までの検討では 解析精度検証用モデル(8)(9)や簡単なモデル(7)での基礎
的な検討がほとんどで，実際の機器への適用に関して の検討，すなわち電圧に関する方程式や運動に関する 方程式との連成に関しての方法, ならびに解析精度, 計算時間についての検討はほとんどなかった。

そこで著者らは，辺要素を用いた三次元磁界解析法 を, 電磁石の過渡動作解析法に拡張するとともに, 上 ンジ形直流電磁石 ${ }^{(1)(2)}$ に応用し, 実器への適用に関し ての有用性を検討した。すなわち，新たに辺要素を用 いた三次元有限要素解析法と電圧に関する方程式なら びに連動方程式を連成させ, 電磁石の動作特性の解析 方法を開発するとともに, 従来の節点要索による万法 と比較検討し，その有用性を明らかにしたので報告 する。

本論文では，まず四面体辺要素を用いた三次元非線 形磁界解析法についての定式化ならびに電圧に関する 方程式との連成方法の詳細について述べた。また，電 
磁石の動作特性の解析手法についても述へた。次に， 本手法をヒンジ形直流電磁石(1)(2)に応用し, 同一要素 分割図を用いて，まず吸引力特性を，辺要素を用いた 本手法による計算結果と従来の節点要素を用いた方法 による計算結果および実測值 ${ }^{(1)}$ と比較検討し, 計算精 度を定量的に明らかにした。更に，過渡動作特性まで も解析し, 従来の節点要素による計算值および実測 値 ${ }^{(2)}$ と比較検討し, 計算精度だけでなく, 記憶容量, 計算時間などについても定量的に示し，本手法の有用 性について明らかにした(10)。これらの検討により， 本手法は, 実際の機器を, 従来法(1)(2) よりも, より高 精度でかつ実用的に解析でき, 計算機支援設計の有用 な手法であることが明らかになった。

\section{2. 解析方法}

\section{〈2・1〉辺要素による三次元非線形磁界解析法}

（1）ガラーキン法による定式化磁気ベクトル ポテンシャルを用いたときの過渡磁界解析に関する基 程式(8)は次式で与えられる。

$$
\operatorname{rot}(\nu \operatorname{rot} A)=J_{0}+J_{e}
$$

ここて，A：は磁気べクトルポテンシャル， $\nu$ : 磁気抵抗率, $J_{0}, J_{e}:$ それぞれ強制電流 密度および渦電流密度

また, 渦電流密度 $\boldsymbol{J}_{e}$ は辺要素を用いるときには, いわゆる電気スカラポテンシャル でちえることができる(6)。

$$
\boldsymbol{J}_{e}=-\sigma \frac{\partial \boldsymbol{A}}{\partial t}
$$

ここて， $\sigma:$ 導電䅸

後述する四面体辺要素の辺 $i て ゙$ 定義されるべクトル 補間関数 $N_{i}$ を重み関数として (1) 式にガラーキン法 を適用し，次式で定義される残差 $G_{i}$ が零となる近似 解を求める。

$$
\begin{aligned}
G_{i}= & \int N_{i}(\operatorname{rot}(\nu \operatorname{rot} A)\} d v-\int N_{i} J_{0} d v \\
& -\int N_{i} J_{e} d v=0 \quad \ldots \ldots \ldots \ldots \ldots \ldots \ldots \ldots \ldots \ldots \ldots \ldots
\end{aligned}
$$

(3)式の第 1 珼を $G_{i i}$ とし, ベクトル公式で変形す ると次式が得られる。

$$
\begin{aligned}
\mathrm{G}_{l i}= & \int \operatorname{rot} \boldsymbol{N}_{i}(\nu \operatorname{rot} \boldsymbol{A}) d v \\
& -\oint \boldsymbol{N}_{i}\{(\nu \operatorname{rot} \boldsymbol{A}) \times \boldsymbol{n}\} d S
\end{aligned}
$$

ここで，自然境界条件(9)を(4)式に適用すれば解析 領域の最外面での表面積分は零となる。すなわち, (2)および(4)式から (3)式㹥次式になる。

$$
\begin{aligned}
& G_{i}=\int \operatorname{rot} \boldsymbol{N}_{i}(v \operatorname{rot} A) d v-\int \boldsymbol{N}_{i} \boldsymbol{J}_{0} d v \\
& +\int N_{i}\left(\sigma \frac{\partial A}{\partial t}\right) d v=0
\end{aligned}
$$

（2）一次四面体要素による離散化 図1に示す 一次四面体辺要素を用いたときの相対辺番号leに対 応するベクトル補間関数 $\boldsymbol{N}_{t e}$ は, 次式で定義され $ろ^{(4)(5)}$ 。

$N_{t e}=\lambda_{m e} \operatorname{grad} \lambda_{n e}-\lambda_{n e} \operatorname{grad} \lambda_{m e}$

ここで, $\lambda_{\text {me }}, \lambda_{\text {ne }}$ :それそれ相対節点番号

meおよびneに対応する体積座標

例えば，体積座標 $\lambda_{\text {me }}$ は図 2 に示すように，相対節 点番号 $m e$ に対応する面を底面とする斜線部の四面体 の体積 $V_{m e}$ と要素 $(e)$ の体積 $V_{e}$ の比で定義され, 次 式で表される。

$$
\begin{aligned}
\lambda_{m e}= & \frac{1}{6 V_{e}}\left(a_{m e}+b_{m e} x+c_{m e} y+d_{m e} z\right) \\
& \ldots \ldots \ldots \ldots \ldots \ldots \ldots \ldots \ldots \ldots \ldots \ldots \ldots \ldots \ldots \ldots \ldots \ldots \ldots \ldots \ldots \ldots \ldots \ldots \ldots \\
V_{e}= & \frac{1}{6} \sum_{m e=1}^{4}(-1)^{m e} x_{m e}\left\{y_{n e}\left(z_{o e}-z_{p e}\right)\right. \\
& \left.+y_{o e}\left(z_{p e}-z_{n e}\right)+y_{p e}\left(z_{n e}-z_{o e}\right)\right\} \\
& \ldots \ldots \ldots \ldots \ldots \ldots \ldots \ldots \ldots \\
a_{m e}= & (-1)^{m e}\left\{x_{n e}\left(y_{p e} z_{o e}-y_{o e} z_{p e}\right)\right. \\
& +x_{o e}\left(y_{n e} z_{p e}-y_{p e} z_{n e}\right) \\
& \left.+x_{p e}\left(y_{o e} z_{n e}-y_{n e} z_{o e}\right)\right\}
\end{aligned}
$$

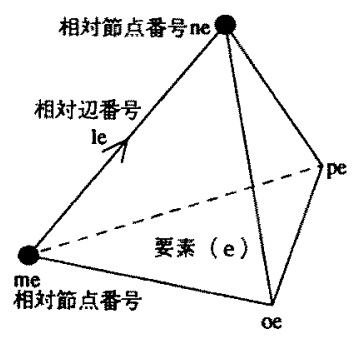

図 1 四面体辺要素

Fig. 1. Tetrahedral edge element.

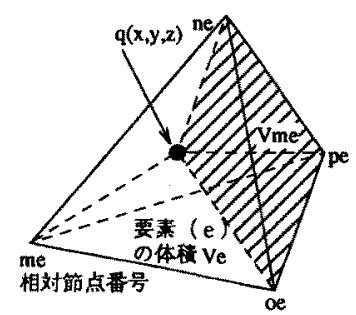

図 2 相対接点番号 me に対応する体積座標 Fig. 2. Barycentric coordinate with respect to node $m e$. 


$$
\begin{aligned}
& b_{m e}=(-1)^{m e}\left\{y_{n e}\left(z_{o e}-z_{p e}\right)+y_{o e}\left(z_{p e}-z_{n e}\right)\right. \\
& \left.+y_{p e}\left(z_{n e}-z_{o e}\right)\right\} \\
& c_{m e}=(-1)^{m e}\left\{z_{n e}\left(x_{o e}-x_{p e}\right)+z_{o e}\left(x_{p e}-x_{n e}\right)\right. \\
& \left.+z_{p e}\left(x_{n e}-x_{o e}\right)\right\} \\
& d_{m e}=(-1)^{m e}\left\{x_{n e}\left(y_{o e}-y_{p e}\right)+x_{o e}\left(y_{p e}-y_{n e}\right)\right. \\
& \left.+x_{p e}\left(y_{n e}-y_{o e}\right)\right\}
\end{aligned}
$$

ここで, me, ne, oe, pe は循環する相対節点番号 て，例えば me=2のときne，oe，pe はそれぞれ 3 , 4，1に対応する。

以上より，(6)式のベクトル補間関数 $N_{L e}$ を用いれ ば, 要素 $(e)$ 内の任意の点 $q(x, y, z)$ における磁気べ クトルポテンシャル $A^{(e)}$ は次式で表すことができる。

$$
A^{(e)}=\sum_{l e=1}^{6} N_{l e} A_{l e}
$$

ここで, $\boldsymbol{A}_{\text {le }}$ : 要素 $(e)$ の相対辺番号 le に対 応する未知変数

すなわち，（6）（13）式を用いれば( 5 )式を離散化 することができる。

（3）非線形解析法 非線形解析にニュートン・ ラプソン法(11)を用いれば，解くべきマトリックスは

(5)式より次式で表される。

$$
\left[\frac{\partial G_{i}^{t+\Delta t}}{\partial A_{l}^{t+\Delta t}}\right]\left\{\delta A_{l}^{t+\Delta t}\right\}=-\left\{G_{i}^{t+\Delta t}\right\}
$$

ここで， $\partial G_{i}^{t+\Delta t} / \partial A_{i}^{t+\Delta t}$ は次式で表される。ただ し, 時間微行項は後退差分近似し(11), 等方性の磁性 体についてのみ述べる。

$$
\begin{aligned}
\frac{\partial G_{i}^{t+\Delta t}}{\partial A_{l}^{t+\Delta t}} & \\
= & \sum_{\Omega}\left\{\int \operatorname{rot} \boldsymbol{N}_{i}^{(e)}\left(\nu^{(e)} \operatorname{rot} \boldsymbol{N}_{l}^{(e)}\right) \delta_{i}^{(e)} \delta l^{(e)} d v\right. \\
& +2 \frac{\partial \nu^{(e)}}{\partial\left(\boldsymbol{B}_{++\Delta t}^{(e)}\right)} \int\left(\operatorname{rot} \boldsymbol{N}_{l}^{(e)} \boldsymbol{B}_{t+\Delta t}^{(e)}\right) \\
& \left.\times\left(\operatorname{rot} \boldsymbol{N}_{i}^{(e)} \boldsymbol{B}_{++\Delta t}^{(e)}\right) \delta_{l}^{(e)} \delta l^{(e)} d v\right\} \\
& +\sum_{\Gamma j e} \frac{1}{\Delta t} \int \boldsymbol{N}_{i}^{(e)}\left(\sigma^{(e)} \boldsymbol{N}_{l}^{(e)}\right) \delta_{l}^{(e)} \delta l^{(e)} d v
\end{aligned}
$$

ここで, $\Omega, \Gamma_{j e}:$ そぞれ全領域掞よび渦 電流が流れる領域

また， $\boldsymbol{B}_{t+\Delta t}^{(e)}$ は時刻 $t+\Delta t$ に极ける要素 $(e)$ の磁束 密度である。(15)式は, 絶対辺番号 $i$ おび $l$ を有す る要素 (e)についてのみ計算し，それらの和をとれば (14)式のマトリックスが作成できることを表してい る。すなわち， $\delta^{(e)}$ 抢よび $\delta l^{(e)}$ がこれを表す関数であ

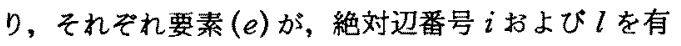
するとき1，それ以外のとき0になる。なお，(15) 式
に積分公式を適用して得られる(14)式の倸数マトリッ クスは対称となることから, ICCG 法(12)が適用可能で ある。また，(15)式の $\partial \nu^{(e)} / \partial\left(\boldsymbol{B}_{t+4 t}^{(e) 2}\right)$ は, 磁化曲線加 ら求められる(11)。なお，線形解析ではこれを零とし て1回計算すればよい。

（4）電圧が与えられた有限要素法 電圧が印加 された場合の過渡解析では巻線に流れる電流 $I_{0}$ は未 知であるため，電圧に関する方程式も解かなければな らない。しかし，辺要素に関する従来の検討(7) (9) は, 前述の (1) 式の解析のみであるので, そのままでは実 際の機器への適用は困難である。そこで, 前述の電流 が与えられたときの辺要素を用いた三次元有限要素解 析法を拡張し, 電圧が与えられた有限要素解析法につ いて述べる。

電圧に関する方程式は次式で与えられる(13)。

$$
E=V_{0}-R I_{0}-L \frac{d I_{0}}{d t}-\frac{d \Psi}{d t}=0
$$

ここて， $V_{0}, R, L, I_{0}:$ そぞれ巻線の端 子電圧, 実效抵抗, 解析領域外のインダクタ ンスおよび強制電流

また， $\Psi$ は巻線との総鎖交磁束数で次式で与えら れる(13)。

$$
\Psi=\frac{n_{c}}{S_{c}} \int(\oint A d s) d S
$$

ここで， $n_{c} ， S_{c}:$ それでれ巻線の巻数およ び断面積， $d s$ : 電流が流れる方向に沿った 微小線分, $d S$ : 巻線の断面における微小面積 微小線分 $d s$ の方向は巻線の断面の単位法線ベクト $ル \boldsymbol{n}_{\boldsymbol{s}}$ と同じであるから，(17)式は次式で表される。

$$
\begin{aligned}
& \Psi=\frac{n_{c}}{S_{c}} \int \boldsymbol{A} \boldsymbol{n}_{s} d v \cdots . . . . \\
& \text { ここで, } d v: \text { 巻線領域 }
\end{aligned}
$$

また, 巻線に流れる電流 $I_{0}$ と強制電流密度 $J_{0}$ の関 係は次式で表される。

$$
J_{0}=\frac{n_{c}}{S_{c}} I_{0} n_{s}
$$

(19)式を(5)式へ代入すれば電流 $I_{0}$ を含む項の残 差 $G_{j o t}^{(e) t+\Delta t}$ は次式で表される。

$$
G_{j 0 i}^{(e) t+\Delta t}=\sum_{\Gamma_{j 0}} \frac{n_{c}}{S_{c}} I_{0}^{t+\Delta t} \int N_{i}^{(e)} n_{s}^{(e)} \delta_{i}^{(e)} d v
$$

（20）式を用いた（5)式と（16)式を連立させ, 前述の ニュートン・ラプソン法を用いれば, 解くべきマトリ ックスは次式で表される。 


$$
\begin{aligned}
& {\left[\begin{array}{ll}
{\left[\frac{\partial G_{i}^{t+\Delta t}}{\partial A_{i}^{t+\Delta t}}\right]} & \left\{\frac{\partial G_{i}^{t+\Delta t}}{\partial I_{0}^{t+\Delta t}}\right\} \\
\left\{\frac{\partial E^{t+\Delta t}}{\partial A_{l}^{t+\Delta t}}\right\} & \frac{\partial E^{t+\Delta t}}{\partial I_{0}^{t+\Delta t}}
\end{array}\right]\left\{\begin{array}{c}
\left\{\delta A_{l}^{t+\Delta t}\right\} \\
\delta I_{0}^{t+\Delta t}
\end{array}\right\}} \\
& =-\left\{\begin{array}{c}
\left\{G_{i}^{t+\Delta t}\right\} \\
E^{t+\Delta t}
\end{array}\right\} \\
& \frac{\partial G_{i}^{t+\Delta t}}{\partial I_{0}^{t+\Delta t}}=-\frac{n_{c}}{S_{c}} \sum_{\Gamma_{0}} \int N_{i}^{(e)} n_{s}^{(e)} \delta_{i}^{(e)} d v \\
& \frac{\partial E^{t+\Delta t}}{\partial A_{l}^{t+\Delta t}}=-\frac{n_{c}}{S_{c}} \frac{1}{\Delta t} \sum_{\Gamma_{s_{0}}} \int N_{l}^{(e)} n_{s}^{(e)} \delta l^{(e)} d v \\
& \frac{\partial E^{t+\Delta t}}{\partial I_{0}^{t+\Delta t}}=-R-\frac{L}{\Delta t}
\end{aligned}
$$

ここで，(21)式の $\partial G_{i}^{t+\Delta t} / \partial A_{t}^{t+\Delta t}$ は通常の強制電流 密度が与えられた場合の(15)式と同じである。また, $\partial G_{i}^{t+\Delta t} / \partial I_{0}^{t+\Delta t}$ および $\partial E^{t+\Delta t} / \partial A_{l}^{t+\Delta t}$ は (22)，(23) 式か らわかるように，(21)式の下段の電圧に関する行に $\Delta t$ を乗じれば，マトリックスは対称になり，マトリ ックスの解法に ICCG 法が適用可能となる。

〈2・2〉可動鉄心に働く電磁力の解析法 電磁石 の可動鉄心に働く電磁力の解析には，マクスウェルの 応力法(2)(14)を用いる。なお，可動鉄心は回転運動する ので，トルクを計算する必要がある。この可動鉄心に 働くトルクの計算法の詳細は文献 (2)に譲る。

\section{〈2・3〉 可動鉄心の動作特性を考慮した解析法}

電磁石の可動鉄心は回転運動するので，回転運動方 程式を考慮し解析しなければならない。また，動作に よって変化する可動鉄心部分の分割だけでなく, 可動 鉄心と固定鉄心間のギャップ中の分割も, 要素が潰れ たり重ならないように自動的に修正しなければならな い。すなわ方，可動鉄心の回転運動方程式および移動 量を時間刻み幅 $\Delta t$ ごとに計算し，分割図を自動修正 すれば，動作特性の解析が可能である。なお，可動鉄 心の回転運動方程式および移動量の計算方法の詳細は 文献( 2 )，(15) に譫る。

\section{3. 解析モデル}

図 3 に解析モデルである直流電磁石(1)(2)を示す。七 ンジ部に $0.1 \mathrm{~mm}$ のギャップを設けてあるのは，鉄心 の非磁性めつきを考慮しているのと，可動鉄心のナイ フエッジ部の加工精度 (接触面の粗さ)が測定結果に及 ほす影崤を小さくするためである。図4に解析に用い た可動鉄心，固定鉄心拉よびコイル部の三次元分割図 を示す。また，空気部の分割は，後述の磁束の漏れを

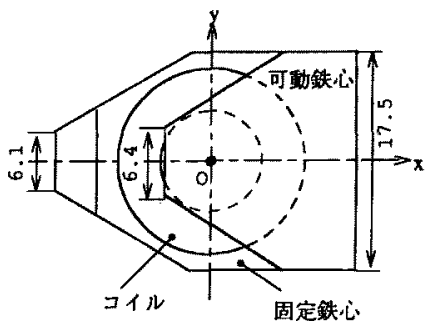

(a) 平面図

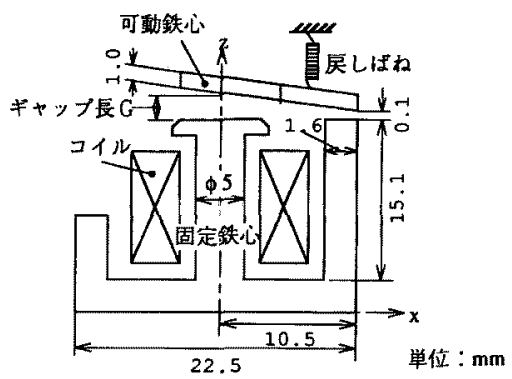

(b) 正面図

図 3 ヒンジ形直流電磁石

Fig. 3. Clapper type DC electromagnet.
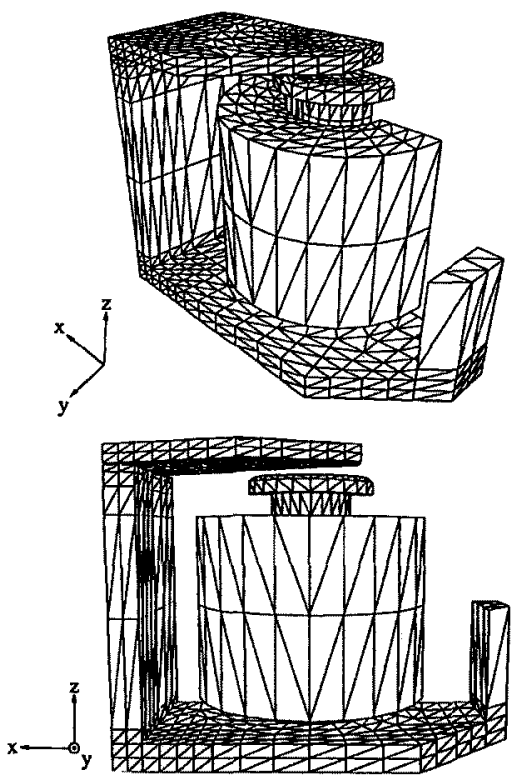

図 4 三次元分割図(鉄心およびコイル部)

Fig. 4. 3-D meshes of cores and coil.

十分に考慮できるようにした。なお，この三次元分割 は解析精度の検討を容易にするため, 文献 (1)，（2） で検討したときのものよりもかなり粗くなるように, 新たに作成した。また, 図 5 にマクスウェルの応力法 による電磁力の計算に用いる積分面の取り方(1)を示 


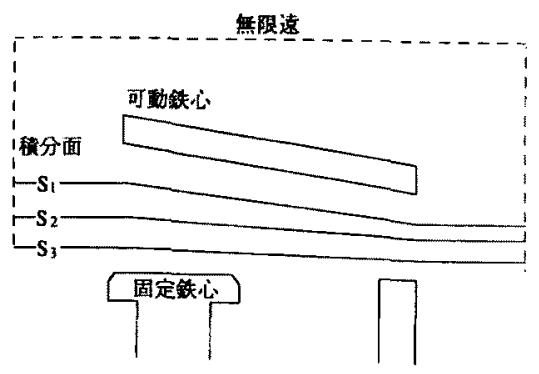

図 5 積分面 $S$ のとり方

Fig. 5. Positions of integral surface $S$.

す。なお, 図 5 に破線で示す無限遠では, 磁束密度 $\boldsymbol{B}$ は零になるので, 同図に実線で示す積分面 $S_{1} \sim S_{3}$ のみにおける磁束密度の計算值を用いて電磁力を計算 した。解析領域は磁束分布の対称性から全体の 1/2 領 域とし，辺要素および節点要素を用いて吸引力特性お よび過渡動作特性を解析し, 実測值(1)(2) と比較するこ とにより精度を検討するとともに，記憶容量および計 算時間を比較㭘討する(16)。なお本論文では，可動鉄 心が固定鉄心に吸着するまでの間の動作特性の検討で

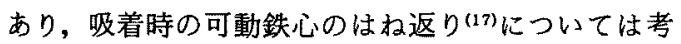
慮していないので，過渡解析ておける時間刻み幅 $\Delta t$

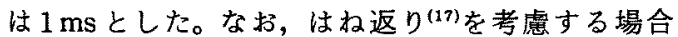
は，時間刻み幅 $\Delta t$ をかなり小さくする必要がある。 また，渦電流の有無が動作時間に及沽す影響について も検討した。マトリックスの解法には加速係数を導入 したICCG 法(12)を用いた。な扔, 加速係数 $\gamma$ は四面 体辺要素では $\gamma=1.02$, 節点要素では $\gamma=1.2$ とした。 また, ICCG 法の収束判定值は, 最大ポテンシャルの $10^{-8}$ 倍として, ニュートン・ラプソン法の収束判定值 は，磁束密度の修正量が $10 \mathrm{G}$ 以下とした。

\section{4. 解析結果と検討}

〈4・1〉吸引力特性 図 6 に, 辺要素および節点 要素を用いて非線形静磁界解析したときのギャップの 長さ $G$ および積分面のとり方が, 電磁力の計算值に 及ほす影響を示す。なお，非線形性の影響も検討する ために，定格の励磁電流の $100 \%$ だけでなく $70 \%$ の場 合についても検討する。また，図中には実測值(1)も示 す。この図からわかるように，ギャップの長さ $G か ゙$ 大きいときは, 辺要素扔よび節点要素を用いたときの 計算値は実測値とかなりよく一致していることがわか る。しかし，ギャップの長さが小さいときには辺要素 を用いたときの計算值は実測值とよく一致している が，節点要素を用いたときの計算値は実測值よりも小

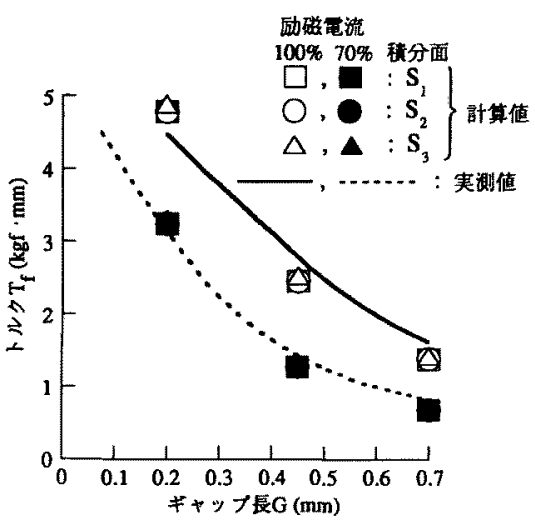

(a) 辺要素

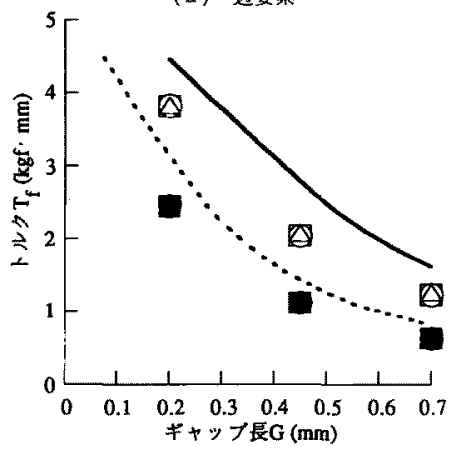

(b) 節点要素

図 6 吸引力特性

Fig. 6. Attractive force characteristics.

さく計算されていることがわかる。このことから，本 モデルでは節点要荸を用いて解析すると, 三次元分割 が粗いときには電磁力が小さく計算されるが, 辺要素 では同じ分割図でも，より精度良く計算されることが わかる。

〈4・2〉過渡動作特性 図 7 に, 辺要素拈よび節 点要素を用いた場合の励磁電流の時間的変化の計算値 を実測值(1)(2) と対比して示す。可動鉄心が固定鉄心に 吸引されていくに従い，インダクタンスの増加により 励磁電流が一時的に隇少する現象までも，正確にシミ ユレーションしていることがわかる。また, 辺要素に よる計算値は実測值とよく一致して扔り，本解析法の 妥当性がわかる。また，節点要素による計算值も実測 值とかなりよく一致しているが，可動部が吸着してか らあとは辺要素を用いた場合のほうが多少精度が良い ことがわかる。また，渦電流により動作時間は遅くな ることが定量的にわかる。

図 8 に，それぞれ辺要萃および節点要素を用いたと きの時刻 $t=8 \mathrm{~ms}$ に㧍ける磁束密度べクトル図の一 


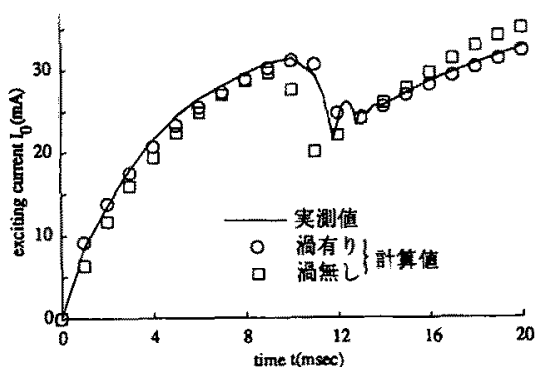

(a) 辺婪素

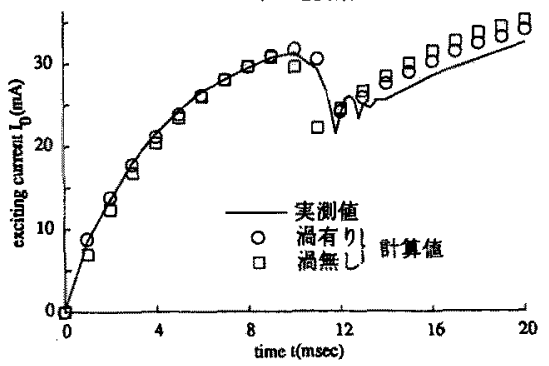

(b) 飾点要案

図 7 励磁電流の時間的変化

Fig. 7. Waveformes of exciting current.

例を示す。この図からかかるように，表皮効果のため 磁束が鉃心の表面に集中していることがかかる。表皮 効果が表れる場合は，鉄心の表面を細かくく分割する必 要加ある。しかし，(a)，(b)図を比較すると，同じ 分割図を用いているにもか加らず，辺要素を用いて 計算したときのほうが，節点要素を用いて計算したと きよりも定性的に正しい解が得られていることがかが る。すなわち, 本モデルの場合には辺要素のほうが, 節点要素より精度良く計算できることがわかる。

〈4・3〉解析啫元 表 1 に解析諸元を示す。同表 からすかるように，本例程度の分割図では，ワークス テーションを用いて数時間で，非線形かよび洞電流ま て考慮して，動作特性の解析的检討が可能であること がわかる。また, 辺要素と節点要素の比較では, 辺要 素を用いたときには，末知交数の量は節点要素を用い たときと比較してかなり多くなることがわかる。しか し，計算に必要な記譩容量の大部分を占めるマトリッ クスの非零要素数は, 渦電流を無視したときは両者は ばとんど同じであるが，渦電流を考慮したときはかえ って節点要素よりも少なくなっていることがわかる。 また，維計算時間は，渦電流を無視したときには，辺 要素を用いたほうが節点要素を用いたときの1/2以下 であることがわかる。しかし，渦電流を考慮したとき には，活とんど同じであることがかかる。なお，表中

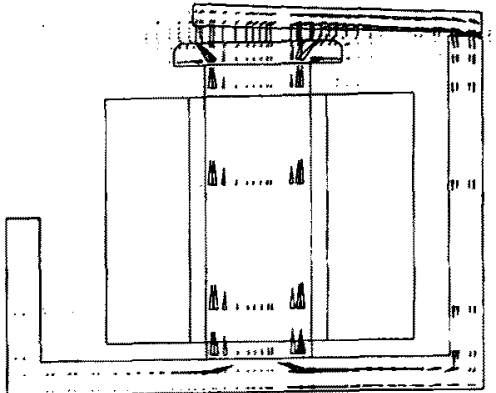

(a) 迎要素

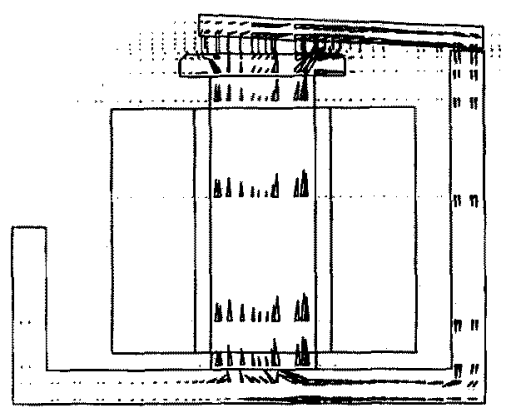

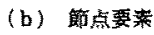

図 8 磁束密度べクトル図 $(t=8 \mathrm{~ms})$

Fig. 8. Distributions of flux density vectors.

表 1 解析諸元

Table 1. Discretization data and CPU time.

\begin{tabular}{|c|c|c|c|c|}
\hline & \multicolumn{2}{|c|}{ 渦電流を無視 } & \multicolumn{2}{|c|}{ 渦電流老考虚 } \\
\hline & 议要素 & 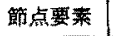 & 辺要素 & 節点要咪 \\
\hline 要素数 & \multicolumn{4}{|c|}{28,134} \\
\hline 節点数 & \multicolumn{4}{|c|}{5,624} \\
\hline 辺数 & \multicolumn{4}{|c|}{35,520} \\
\hline 来知数 & 30,232 & 12,020 & 30,232 & 13,246 \\
\hline $\begin{array}{l}\text { マトリックスの } \\
\text { 非旿要靠数 }\end{array}$ & 248,837 & 245,953 & 248,837 & 302,451 \\
\hline ステップ数 & \multicolumn{4}{|c|}{20} \\
\hline $\begin{array}{l}\text { ICCG 法の } \\
\text { 平均反復回数 }\end{array}$ & 84.7 & 223.7 & 214.1 & 203.9 \\
\hline $\begin{array}{l}\text { ニュートン・ } \\
\text { ラプソン法の } \\
\text { 平均反隻回数 }\end{array}$ & 4.3 & 6.2 & 5.1 & 4.6 \\
\hline 総棓笛時等間 (h) & 2.4 & 6.5 & 5.6 & 5.7 \\
\hline
\end{tabular}

使用計算機：日商エレタトロニクス(株) 㪙 HelioStation $1030 \mathrm{~S}$

の総計算時間は，ICCG 法の収束過程をグラフィック スによって表示する時間なども含む。これらの計算時

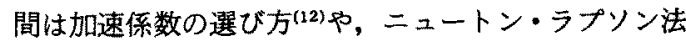
の収束判定值の設定によっても翼なるのて，今後，辺 要素を用いた渦電流解析の高速化を含めて，更に检討 
する必要がある。

\section{5. むす}

辺要素を用いた電磁石の過渡動作解析を新しく開発 した。本手法と, 従来から用いられている節点要素を 用いる方法を定量的に比較検討した。本研究により得 られた知見を要約すると以下のようになる。

（1）本モデルの静的な吸引力特性解析では, 三次 元分割図が同じでも，辺要素を用いたときのほうが節 点要素を用いたときよりも精度が良いことが明らかと なった。

（2）過渡動作解析では，鉄心に流れる渦電流およ び非線形性を考慮して得られた計算值は実測值と非常 によく一致した。このことから，本モデルでは鉄心に 流れる渦電流と非線形性を考慮して解析しなければな らないことが明らかとなった。

（3）辺要素を用いたとき，末知数は節点要素を用 いたときよりもかなり多くなるが，計算に必要な記憶 容量の大部分を占めるマトリックスの非零要素数は, 節点要素を用いたときよりも少なくなることから，記 憶容量の面からも有利であることが明らかとなった。

（4）総計算時間は，渦電流を無視したときには, 辺要素を用いたほうが，節点要素を用いたときの $1 / 2$ 以下であるが，渦電流を考慮したときにはほとんど同 じであることが明らかになった。

今後は, 辺要素を用いた場合の渦電流計算の高速 化, 分割と精度の関係の体系的検討を行う予定で ある。

最後に, 常々御指導をいただいております岡山大学 工学部教授中田高義先生に深謝いたします。また, 本研究の試料および実測結果を提供いただいた富士電 機(株) 石川氏はじめ，関係各位に深謝いたします。

(平成 5 年 1 月 20 日受付, 同 5 年 5 月 14 日再受付)

\section{文献}

(1) Y. Kawase, H. Kikuchi \& S. Ito: “3-D Non-linear Analysis of Dynamic Behavior of the Clapper Type DC Electromagnet", IEEE Trans. Magnetics, MAG-27, No. 5, 4238 (1991)

（2）河瀬・菊地 - 伊藤 : 「直流電磁石の過渡動作特性の三次元数 值解析」, 電学論 B, 111, 1051 (平 3-10)

（3）羽野：「辺要素による三次元渦重流解析一何故に辺要素が必 要か一1, 平 3 電気学会全大, S. 11-3

(4) A. Bossavit: "Whitney Forms: a Class of Finite Elements for Three-Dimensional Computations in Electromagnetism", IEE Proc, 135, Pt. A, No. 8, 493 (1988)
(5) M. L. Barton \& Z. J. Cendes: "New Vector Finite Elements for Three-Dimensional Magnetic Field Computation", IEEE J. Appl. Phys., 61, No. 8, 15, 3919 (1987)

(6) A. Kameari, "Calculation of 3-D Eddy Current using Edge Elements", IEEE Trans. Magnetics, MAG-26, No. 2, 466 (1990)

(7) Y. Kawase, H. Kikuchi \& Z. J. Cendes: "3-D Finite Element Analysis of Electromagnetic Forces using Edge Elements: "IEEE Conference on Electromagnetic Field computation, WOB5 (1992)

(8) T. Nakata, N. Takahashi \& K. Fujiwara: "Investigation of a Model to Verify Softwares for 3-D Nonlinear Eddy Current Analysis", IEEE Trans. Magnetics, MAG-26, No. 2, 501 (1990)

（9）藤原：「辺要素を用いた三次元磁界解析」, 第 2 回電嘫界数 值解析に関するセミナ講演論文集, 7 (平 3)

（10）河瀬・菊地：「四面体辺要素を用いた直流重磁石の過渡動作 特性の三次元有限要素解析」, 電気学会静止器・回転機合同研 資, SA-92-17; RM-92-52 (平 4)

（11）中田・高橋：電気工学の有限要素法, 第 2 版（平 4) 森北出 版

（12）藤原・中田・房安：「ICCG 法の高速化手法に関する検討」, 電気学会静止器 - 回転合同機研資, SA-91-43; RM-91-106 (平3)

(13) T. Nakata, et al.: "3-D Finite Element Method for Analyzing Magnetic Field in Electrical Machines Excited from Voltage Source", IEEE Trans. Magnetics, MAG-24, No.6, 2582 (1988)

(14) 竹山：電磁気学現象理論 (昭 57) 丸善

（15）河瀬・宮谷・山口・伊藤・中村：「フラット形電磁石の過渡 動作特性の三次元有限要素解析」, 平 5 電気学会全大, No 973

（16）河瀬：「数值解析技術の進步」, 平 5 同上, S. 13-3

（17）河瀬・村井・伊藤：「単相交流電磁石の吸引力特性の解析」, 電学論 $\mathrm{D}, 109,500$ (平元-7)

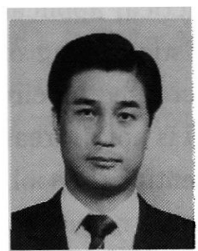

河 瀬 順 洋 (正員)

昭和 31 年 4 月 24 日生。 56 年 3 月岡 山大学大学院工学研究科電気工学専攻修 士課程修了。同年 4 月同大学電気工学科 助手。6 60 年 4 月岐阜大学工学部電気工 学科助手, 63 年 6 月同電子情報工学科助教授, 現在に至 る。工学博士。6 0 年電気学会論文賞, 平成元年電子情報 通信学会東海支部創立 50 周年記念奨励賞受賞。

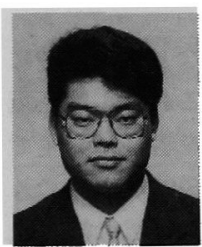

菊 地 春 秀 (正員)

昭和 42 年 10 月 14 日生。平成 4 年 3 月岐阜大学大学院工学研究科電気工学専 攻修士課程修了。同年 4 月 (株)電算シス テム入社, 現在に至る。 